УДК $632.95: 634.8$

DOI: $10.30679 / 2219-5335-2018-4-52-68-74$

ТОКСИЧНЫЕ ОСТАТКИ

ОРГАНИЧЕСКИХ ФУНГИЦИДОВ

В АНТРОПОГЕННО-

ТРАНСФОРМИРУЕМОЙ ПОЧВЕ АМПЕЛОЦЕНОЗОВ

Воробьева Татьяна Николаевна

д-р с.-х. наук, профессор

главный научный сотрудник

научного центра «Защиты

и биотехнологий растений»

e-mail: toksikolog@ mail.ru

Подгорная Марина Ефимовна канд. биол. наук

зав. лабораторией защиты

плодовых и ягодных растений

e-mail: plantprotecshion@yandex.ru

Федеральное государственное бюджетное научное учреждение

«Северо-Кавказский федеральныи

научный иентр садоводства,

виноградарства, виноделия»,

Краснодар, Россия

Воздействие токсичных химикатов на агроугодья виноградных насаждений и смежных территорий усиливается по причине включения в состав новых препаратов ранее применяемых действующих веществ, характеризующихся как высокотоксичные соединения.

Эколого-токсикологическую опасность для экосистемы ампелоценозов представляют препараты длительно сохраняющиеся, прежде всего, в почве обрабатываемых ими виноградников. Их агрессивность к микробам и бактериям ускоряет процессы деградации почвы, а частичная миграция в экосистеме «почва растения -виноград» загрязняет продукцию токсичными химикатами. Органические фунгициды системного действия триазольной группы (фалькон, универсал, колосаль, колосаль Про) объединяет наличие в их составе действующего вещества тебуконазола, отличающегося
UDC $632.95: 634.8$

DOI: 10.30679/2219-5335-2018-4-52-68-74

\section{TOXIC RESIDUES OF ORGANIC FUNGICIDES IN THE ANTROPOGENIC TRANSFORMING SOIL OF AMPELOCENOSES}

Vorobyova Tatyana Nikolayevna

Dr. Sci. Agr., Professor

Chief Research Associate

of Research center «Protection and Biotechnology of Plants» e-mail: toksikolog@ mail.ru

Podgornaya Marina Efimovna Cand. Biol. Sci.

Head of Laboratory of Protection of Fruit and Berry plants

e-mail: plantprotecshion@yandex.ru

Federal State Budget

Scientific Institution

"North Caucasian Federal

Scientific Center of Horticulture,

Viticulture, Wine-making»,

Krasnodar, Russia

The impact of toxic chemicals on the vineyards and adjacent areas is enhanced due to inclusion in the new preparations of previously used active substances, characterized as highly toxic substances. Ecological and toxicological danger for the ecosystem of ampelocenoses is represented by preparations of long storage, primarily in the soil of the vineyards these preparation used. Their aggressiveness to microbes and bacterias speeds up the processes of soil degradation, and their partial migration in the ecosystem "soil-plant-grapes" pollutes the products with toxic chemicals. Organic fungicides of the systemic action of the triazole group (falcon, wagon, colossal, spike) are combined by the presence in their composition of the tebuconazole active substance, distinguished by the duration and stability 
длительностью и стабильностью сохранения в экосистеме ампелоценозов. Цель настоящей работы - изучение взаимосвязи техногенной нагрузки фунгицидов, содержащих тебуконазол, и экологотоксикологического состояния ампелоценозов. Определение токсичных остатков проводилось по общепринятым методикам с использованием хроматографов: газового «Цвет 500М», жидкостного «KNAUER» и атомно-абсорбционного спектрофотометра «Квант -АФА». Исследования проводили в основной агроэкологической зоне виноградарства Темрюкского района Краснодарского края (АО агрофирма «Южная») на двух участках виноградника площадью 5 га при одинаковых условиях их агросодержания. 1 вариант - ежегодные производственные обработки фунгицидами, содержащими тебуконазол; 2 вариант в последний год исследований изучаемые фунгициды не применялись: они были заменены системными фунгицидами другой группы и это позволило определить загрязненность винограда тебуконазолом, мигрирующим из почвы.

В результате проведения исследований установлены персистентные и кумулятивные свойства тебуконазола, аккумулируемого почвой, в 5 раз превышающие допустимые нормы. Выявлено загрязнение винограда почвенными токсичными остатками тебуконазола.

Ключевые слова: ФУНГИЦИДЫ, ТЕБУКОНАЗОЛ, ПОЧВА, ВИНОГРАД, ТОКСИЧНЫЕ ОСТАТКИ of preservation in the ecosystem of ampelocenoses. The purpose of this work is to study the interconnection of the technogenic fungicides load containing tebuconnazole, and the ecological-toxicological state of ampelocenoses. The determination of the toxic residues was carried out according to generally accepted methods using chromatographs: gas "Color 500M", liquid "KNAUER" and atomic absorption spectrophotometer "Kvant-AFA".

The research was carried out in the main agroecological viticulture zone of Temryuk district of the Krasnodar Territory (Agrofirm "Yuzhnaya") in two vineyard plots with an area of 5 hectares, under the same agrical and technological conditions. Option 1 - annual industrial treatment with fungicides containing tebuconazole; Option 2 - in the last year of study the fungicides studied were not used: they were changed by system fungicides of another group and this change allow us to determine the contamination of grapes with tebuconazole, migrating from the soil. As a result of the research, it was established, that the persistent and cumulative properties of tebuconazole, accumulated by soil, in 5 times higher than the permissible standards. The contamination of grapes with toxic residues of tebuconazole has been revealed.

Key words: FUNGICIDES, TEBUCONAZOLE, SOIL, GRAPES, TOXIC RESIDUES

Введение. Нежелательное воздействие токсичных химикатов на агроугодья виноградных насаждений и смежных территорий обостряется включением в состав новых препаратов ранее применяемых действующих веществ, характеризующихся как высокотоксичные соединения. Несмотря на существующую проблему объем научной литературы по экологотоксикологическим исследованиям многолетних насаждений незначите- 
лен. Эколого-токсикологическую опасность для экосистемы ампелоценозов представляют препараты длительно сохраняющиеся, прежде всего, в почве обрабатываемых ими виноградников [1-5]. Их агрессивность к микробам и бактериям ускоряет процессы деградации почвы [6, 7], а частичная миграция в экосистеме «почва-растения-виноград» загрязняет продукцию токсичными химикатами. К ним относятся органические фунгициды системного действия триазольной группы (фалькон, универсал, колосаль), в состав которых входят действующие вещества, отличающиеся по длительности их сохранения в экосистеме [8]. Поэтому изучение взаимосвязи техногенной нагрузки этих препаратов и эколого-токсикологического состояния ампелоценозов, послужило целью представленной работы.

Объекты и методы исследований. Объект исследований - виноградный участок технического сорта Первенец Магарача, схема посадки 4×2 м, формировка двусторонний кордон, насаждения 2010 года. Исследования проводили в основной агроэкологической зоне виноградарства Краснодарского края - Темрюкском районе (3-е отделение АО агрофирмы «Южная») на двух участках площадью 5 га при одинаковых условиях их содержания [9]. На одном из них (вариант 1) - ежегодные производственные обработки фунгицидами различных групп, включая изучаемые препараты; на другом (вариант 2) - в последний год исследований изучаемые фунгициды не применялись: они были заменены системными фунгицидами другой группы. Это позволило определить в ягодах винограда концентрацию изучаемых фунгицидов, мигрирующих из почвы. В состав изучаемых органических фунгицидов триазольной группы входили фалькон, универсал, колосаль, колосаль ПРО, содержащие высокотоксичное д.в., тебуконазол.

Определение токсичных остатков проводилось по общепринятым методикам [10] с использованием хроматографов, газового «Цвет 500М» и жидкостного «KNAUER» на оборудовании Центра коллективного пользования ФГБНУ СКФНЦСВВ. 
Плодоводство и виноградарство Юга России № 52(04), 2018 г.

Обработка экспериментального материала - специальные компьютерные программы (Microsoft Excel 2007; Statistica 6.0 for Windows) и coвременная электронно-вычислительная техника.

Обсужнение результатов. Опытный участок обрабатывался изучаемыми фунгицидами в течение нескольких лет. Обработки проводились по регламентированной норме расхода каждого препарата (табл. 1), что не всегда гарантирует детоксикацию изучаемых фунгицидов до безопасных величин [11]. В этом случае прежде всего настораживает состояние почвы, аккумулирующей те соединения, которые имеют нелабильную форму, но в то же время частично мигрируют в экосистеме почва-растение-продукция.

Таблица 1 - Регламенты применения фунгицидов на виноградниках

\begin{tabular}{|c|c|c|c|c|c|}
\hline \multirow{3}{*}{ Фунгицид } & \multirow{2}{*}{\multicolumn{2}{|c|}{$\begin{array}{c}\text { Санитарно-гигиенические } \\
\text { регламенты, мг/кг }\end{array}$}} & \multirow{3}{*}{$\begin{array}{c}\text { Число } \\
\text { обработок, } \\
\text { 1/год }\end{array}$} & \multicolumn{2}{|c|}{ Расход в обработке } \\
\hline & & & & \multirow{2}{*}{$\begin{array}{c}\text { фунгицида, } \\
\text { кг (л)/га }\end{array}$} & \multirow{2}{*}{$\begin{array}{c}\text { д.в. г/кг (л) } \\
\text { рабочей } \\
\text { смеси }\end{array}$} \\
\hline & почва (ПДК) & $\begin{array}{c}\text { продукция } \\
\text { (МДУ) }\end{array}$ & & & \\
\hline Фалькон & $0,4+0,4+0,02$ & $2,0+2,0+2,0$ & 4 & 0,4 & $250+167+43$ \\
\hline Универсал & 0,4 & 2,0 & 4 & 0,3 & 500 \\
\hline Колосаль & 0,4 & 2,0 & 4 & 0,4 & 250 \\
\hline $\begin{array}{l}\text { Колосаль Про } \\
\text { КМЭ }\end{array}$ & $0,4+0,4$ & 2,0 & 4 & 0,3 & $300+200$ \\
\hline
\end{tabular}

Примечание: ПДК - предельно допустимая концентрация; МДУ - максимально допустимый уровень; д.в - действующее вещество

Указанные фунгициды отмечаются однокомпонентным, двухкомпонентным и трехкомпонентным составом д.в., что отличает их не только по защитной эффективности против грибных болезней, но и по изучаемому вопросу длительности их сохранения и влияния на экосистему ампелоценозов. Это зависит от количественного состава и физико-химических свойств компонентов д. в. каждого из препаратов. Исследуемые препараты объединяло наличие в их составе д. в. тебуконазола, отличающегося длительностью и стабильностью сохранения в почве после обработок (табл. 2).

Для определения кумулятивных и персистентных свойств фунгицидов отбор проб почвы виноградников проводился на участке (вариант 1) 
Плодоводство и виноградарство Юга России № 52(04), 2018 г.

осенью после обработок фунгицидами. Этот участок ежегодно обрабатывался хотя бы одним из изучаемых препаратов, в состав которых входил (д.в.) тебуконазол. Эколого-токсикологическая опасность изучаемых фунгицидов оценивалась по содержанию токсичных остатков тебуконазола в почве и винограде (табл. 3,4$)$.

Таблица 2 - Компоненты (д.в.), входящие в состав фунгицидов

\begin{tabular}{|l|l|l|}
\hline \multicolumn{1}{|c|}{ Фунгицид } & \multicolumn{1}{|c|}{ Действующее вещество (д.в.) } & \multicolumn{1}{c|}{$\begin{array}{c}\text { Количество (д.в), } \\
\text { г/кг; мг/л }\end{array}$} \\
\hline Фалькон & Спироксамин+тебуконазол+триадименол & $(250+167+43)$ г/л \\
\hline Универсал, СП & Тебуконазол & 500 г/кг \\
\hline Колосаль, КЭ & Тебуконазол & 250 г/л \\
\hline $\begin{array}{l}\text { Колосаль, } \\
\text { ПРО, КЭ }\end{array}$ & Пропиконазол+тебуконазол & $(300+200)$ г/л \\
\hline
\end{tabular}

Таблица 3 - биотрансформация тебуконазола в почве

\begin{tabular}{|l|c|c|c|c|}
\hline \multirow{2}{*}{$\begin{array}{l}\text { Фунгицид } \\
\text { (д.в. тебуконазол) }\end{array}$} & \multicolumn{4}{|c|}{ Остатки тебуконазола, мг/кг } \\
\cline { 2 - 5 } & Вариант 1 & $\begin{array}{c}\text { Погрешность } \\
\text { измерений }\end{array}$ & Вариант 2 & $\begin{array}{c}\text { Погрешность } \\
\text { измерений }\end{array}$ \\
\hline $\begin{array}{l}\text { Фалькон, КЭ } \\
(167 \text { г/л) }\end{array}$ & 1,80 & $\pm 0,36$ & 1,33 & $\pm 0,26$ \\
\hline $\begin{array}{l}\text { Универсал, СП } \\
\text { (500 г/кг) }\end{array}$ & 2,98 & $\pm 0,59$ & 2,55 & $\pm 0,51$ \\
\hline $\begin{array}{l}\text { Колосаль, КЭ } \\
\text { (250 г/л) }\end{array}$ & 1,95 & $\pm 0,39$ & 1,45 & $\pm 0,29$ \\
\hline Колосаль, ПРО, КЭ & 1,75 & $\pm 0,35$ & 1,15 & $\pm 0,23$ \\
\hline Тебуконазол (д.в.) & & \multicolumn{3}{|c|}{ ПДК 0,4 мг/кг } \\
\hline
\end{tabular}

Примечание: вариант 1 - ежегодные обработки препаратами, содержащими тебуконазол; вариант 2 - обработки в последний год фунгицидами, содержащими тебуконазол не проводились.

Таблица 4 - Миграция тебуконазола из почвы в виноград

\begin{tabular}{|l|c|c|c|c|}
\hline \multirow{2}{*}{$\begin{array}{l}\text { Фунгицид } \\
\text { (д.в. тебуконазол) }\end{array}$} & \multicolumn{4}{|c|}{ Остатки тебуконазола, мг/кг } \\
\cline { 2 - 5 } & Вариант 1 & $\begin{array}{l}\text { Погрешность } \\
\text { измерений }\end{array}$ & Вариант 2 & $\begin{array}{c}\text { Погрешность } \\
\text { измерений }\end{array}$ \\
\hline $\begin{array}{l}\text { Фалькон, КЭ } \\
\text { Универсал, }\end{array}$ & 0,98 & $\pm 0,19$ & 0,76 & $\pm 0,15$ \\
СП (500г/кг) & 1,74 & $\pm 0,34$ & 1,15 & $\pm 0,23$ \\
\hline Колосаль, КЭ (250г/л) & 1,15 & $\pm 0,23$ & 0,97 & $\pm 0,19$ \\
\hline Колосаль, ПРО, КЭ & 1,11 & $\pm 0,22$ & 0,86 & $\pm 0,17$ \\
\hline Тебуконазол (д.в.) & \multicolumn{4}{|c|}{ МДУ 2,0 мг/кг } \\
\hline
\end{tabular}


Плодоводство и виноградарство Юга России № 52(04), 2018 г.

Установлено, что тебуконазол сохраняется в почве в количествах, превышающих предельно-допустимую концентрация (ПДК) в обоих вариантах опыта. Из почвы вместе с элементами питания тебуконазол мигрирует в растение и в ягоды винограда.

Токсичные остатки тебуконазола в почве, длительно не переходящего в лабильную форму, снижают микробную активность и биогенность почвы, в результате ее природные организмы теряют способность разлагать препараты до безопасных уровней.

Заключение. Мутации и резистентность вредителей, адаптирующихся к химикатам, используемых в борьбе с ними на виноградниках, требуют замены пестицидов на более эффективные и высокотоксичные. Перспективной группой таких препаратов считаются органические фунгициды системного действия триазолной группы, содержащие в своем составе д.в. тебуконазол. Показаны персистентные и кумулятивные свойства тебуконазола, аккумулируемого почвой в количествах, превышающих ПДК в 5 раз. Установлено загрязнение винограда почвенными токсичными остатками тебуконазола.

\section{Литература}

1. Федоров, Л.А. Пестициды - токсический удар по биосфере и человеку / Л.А. Федоров, А.В. Яблоков. - М.: Наука, 1999. - 462 с.

2. Trofano J. Effect of simulated acidic rain on retention of pesticides on leaf surfaces / J. Trofano, E.J. Butterfield // Phytopathology. 1984. Vol. 74. N 11. - P. 1377-1380.

3. Воробьева, Т.Н. Динамика экологических проявлений пестицидного техногенеза в экосистеме ампелоценоза / Т.Н. Воробьева // Вестник Российской академии сельскохозяйственных наук. - 2011. - № 2. - С. 59-61.

4. Подгорная, М.Е. Динамика разложения инсектицидов в плодах яблони в период хранения» края // Плодоводство и ягодоводство России. Сборник научных работ. Том XXX. Современные методы защиты плодовых и ягодных насаждений от болезней и вредителей: материалы всероссийского науч.-практ. семинара. - Москва, ГНУ ВСТИСП, 2012. - C. 389-392.

5. Fox, R. Vielfaltige Begrunung, eine wichtige Grundlage fur den inter grierten Weinbau / R. Fox, M. Straub // Winzen. - 1993. - Yg. - 48, 49. - S. 13-18

6. Воробьева, Т.Н. Биотрансформация фунгицидов триазольной группы в экосистеме почва виноград / Т.Н. Воробьева, А.С. Белков // Агротехнический метод защиты растений: материалы 8-ой межд. науч.-практ. конф. (19-23 июня 2017 г.) - Краснодар, 2017. - С. 90-93. 
7. Тихонович, И.А. Симбиозы растений и микроорганизмов: молекулярная генетика агросистем / И.А.Тихонович, Н.А. Проворов. - СПб.: Изд-во С. Петербургского университета, $2009-210 \mathrm{c}$.

8. Frehse H. The perspective of persistence / H. Frehse // Proc. BCPC Symposium: Persistence of insecticide and herbicides. 1976. - P.1-39.

9. Доспехов, Б.А. Методика полевого опыта / Б.А. Доспехов. - М.: Агропромиздат, 1985. $-351 \mathrm{c}$.

10. Методы контроля. Химические факторы. Определение остаточных количеств пестицидов в пищевых продуктах, с/х сырье и объектах окружающей среды // Сборник методических указаний вып. 4 ч. 1 МУК 4.1.1426 - 4.1.1429-03. - М.: Минздрав России, 2004. $-211 \mathrm{c}$.

11. Воробьева, Т.Н. Санитарно-гигиеническая безопасность пищевой продукции в свете ограничения негативного последействия пестицидов в виноградарстве / Т.Н. Воробьева // Вестник РАСХН. - 2009. - № 5. - С. 25-27.

\section{References}

1. Fedorov, L.A. Pesticidy - toksicheskij udar po biosfere i cheloveku / L.A. Fedorov, A.V. YAblokov. - M.: Nauka, 1999. - $462 \mathrm{~s}$.

2. Trofano J. Effect of simulated acidic rain on retention of pesticides on leaf surfaces / J. Trofano, E.J. Butterfield // Phytopathology. 1984. Vol. 74. N 11. - P. 1377-1380.

3. Vorob'eva, T.N. Dinamika ehkologicheskih proyavlenij pesticidnogo tekhnogeneza v ehkosisteme ampelocenoza / T.N. Vorob'eva // Vestnik Rossijskoj akademii sel'skohozyajstvennyh nauk. - 2011. - № 2. - S. 59-61.

4. Podgornaya, M.E. Dinamika razlozheniya insekticidov $\mathrm{v}$ plodah yabloni $\mathrm{v}$ period hraneniya» kraya // Plodovodstvo i yagodovodstvo Rossii. Sbornik nauchnyh rabot. Tom XXX. Sovremennye metody zashchity plodovyh i yagodnyh nasazhdenij ot boleznej i vreditelej: materialy vserossijskogo nauch.-prakt. seminara. - Moskva, GNU VSTISP, 2012. S. 389-392.

5. Fox, R. Vielfaltige Begrunung, eine wichtige Grundlage fur den inter grierten Weinbau / R. Fox, M. Straub // Winzen. - 1993. - Yg. - 48, 49. - S. 13-18

6. Vorob'eva, T.N. Biotransformaciya fungicidov triazol'noj gruppy v ehkosisteme pochva vinograd / T.N. Vorob'eva, A.S. Belkov // Agrotekhnicheskij metod zashchity rastenij: materialy 8-oj mezhd. nauch.-prakt. konf. (19-23 iyunya 2017 g.) - Krasnodar, 2017. S. 90-93.

7. Tihonovich, I.A. Simbiozy rastenij i mikroorganizmov: molekulyarnaya genetika agrosistem / I.A.Tihonovich, N.A. Provorov. - SPb.: Izd-vo S. Peterburgskogo universiteta, $2009-210 \mathrm{~s}$.

8. Frehse H. The perspective of persistence / H. Frehse // Proc. BCPC Symposium: Persistence of insecticide and herbicides. 1976. - P.1-39.

9. Dospekhov, B.A. Metodika polevogo opyta / B.A. Dospekhov. - M.: Agropromizdat, 1985. $-351 \mathrm{~s}$.

10. Metody kontrolya. Himicheskie faktory. Opredelenie ostatochnyh kolichestv pesticidov v pishchevyh produktah, s/h syr'e i ob"ektah okruzhayushchej sredy // Sbornik metodicheskih ukazanij vyp. 4 ch. 1 MUK 4.1.1426 - 4.1.1429-03. - M.: Minzdrav Rossii, 2004. - $211 \mathrm{~s}$.

11. Vorob'eva, T.N. Sanitarno-gigienicheskaya bezopasnost' pishchevoj produkcii v svete ogranicheniya negativnogo posledejstviya pesticidov v vinogradarstve / T.N. Vorob'eva // Vestnik RASKHN. - 2009. - № 5. - S. 25-27. 